Klinička psihologija 11 (2018), 1-2, 5-20

Izvorni znanstveni rad - UDK 159.922.76

DOI: $10.21465 / 2018-K P-1-2-0001$

\title{
STAVOVI PREMA GLUHIM I NAGLUHIM UČENICIMA
}

\author{
Zlatka Kozjak Mikić \\ Zdravstveno učilište \\ Medvedgradska 55, 10000 Zagreb \\ zkozjakm@net.hr \\ Ivana Merlin \\ Škola za medicinske sestre Vinogradska \\ Vinogradska cesta 29, 10000 Zagreb \\ ivana.merlin@gmail.com \\ Karla Mikić \\ studentica, Odsjek za psihologiju, Hrvatski studiji \\ Borongajska cesta $83 \mathrm{~d}, 10000$ Zagreb \\ mikickarla@gmail.com
}

\begin{abstract}
Sažetak
Pored stereotipa o gluhima, kao glavni razlozi krivih medicinskih dijagnoza ove skupine pacijenata identificiraju se nerazumijevanje kulturološkog aspekta gluhoće i nepoznavanje adekvatnog načina komuniciranja s njima (Ubido, Huntington i Warburton, 2002). Za komunikaciju i stavove prema gluhima značajna je kvaliteta prethodnog kontakta s gluhim pojedincima (De Laat, Freriksen i Vervloed, 2013), stoga bi pozitivno iskustvo i pozitivan stav učenika koji se školuju za zanimanja u zdravstvu mogli pridonijeti boljem razumijevanju i kvalitetnijoj komunikaciji s gluhim pacijentima $\mathrm{u}$ njihovu budućem radu. Svrha istraživanja bila je prikupiti podatke o stavovima učenika zdravstvenih škola prema gluhim i nagluhim vršnjacima te njihovoj integraciji u redovne škole, za što je korišten adaptirani Inventar inkluzije gluhih i nagluhih učenika (Hung, 2005). Prikupljeni su podatci o percipiranoj bliskosti s gluhim i nagluhim učenicima, učestalosti prethodnih dobrovoljnih kontakata s gluhim i nagluhim osobama, percepciji razrednog ozračja povezanog s integracijom gluhih učenika u redovne škole te o tome integriraju li škole gluhe/nagluhe učenike ili ne. U istraživanju je sudjelovalo 328 srednjoškolaca u dobi od 15,5 do 16,5 godina, među kojima je bilo 270 djevojaka i 58 dječaka, iz različitih zdravstvenih programa. Percipirana bliskost s gluhim i nagluhim učenicima relativno je visoka, odnosno stavovi su pozitivni. Djevojke su iskazale višu percipiranu bliskost u odnosu na dječake, ali je razlika, iako statistički značajna, vrlo mala. Nisu dobivene razlike u percipiranoj bliskosti ovisno o tome imaju li škole integrirane gluhe učenike ili ne. Učestalost prethodnog dobrovoljnog kontakta s gluhim/nagluhim vršnjacima unutar razreda povezana je s percepcijom bliskosti s njima. Učenici koji imaju pozitivniju percepciju razrednog ozračja s obzirom
\end{abstract}


na posljedice integracije gluhih vršnjaka na osobni i socijalni život unutar razreda te na razredne aktivnosti iskazali su veću percipiranu bliskost s gluhim učenicima, iako su i te razlike vrlo male.

Ključne riječi: učenici zdravstvenih škola, gluhi i nagluhi učenici, zdravstveni djelatnici

\section{UVOD}

Prema podacima Registra osoba s invaliditetom za 2016. godinu, 2,6\% stanovnika Hrvatske (13 461 osoba) ima oštećenje sluha (Benjak, Petreski, Štefančić, Ivanić, Radošević i Vejzović, 2017). Podatak je u skladu s učestalošću u svjetskim razmjerima (Pribanić i Milković, 2016). Usprkos tome što se i dalje evidentiraju kao osobe s invaliditetom, stavovi prema gluhim i nagluhim osobama se mijenjaju od osamdesetih godina prošlog stoljeća te danas u odnosu na njih dominira socijalnokulturološki pristup (Pribanić i Milković, 2016). Dok medicinski pristup gluhoću i nagluhost percipira kao deficit ili invaliditet, kulturološki pristup podrazumijeva da se radi o komunikacijskim specifičnostima te se gluhe i nagluhe osobe percipiraju kao jezična i kulturalna manjina (Meadow-Orlans i Erting, 2000).

Razumijevanje specifičnosti gluhih i nagluhih osoba i pozitivan stav prema njima iznimno su važni u svim aspektima života, pa tako i u području pružanja i primanja zdravstvenih usluga. Komunikacijski problemi i nerazumijevanje specifične kulture gluhih identificiraju se kao glavni razlozi teškoća u radu s gluhim pacijentima i postavljenih krivih medicinskih dijagnoza ove skupine pacijenata (Denmark, 1994; Ubido i sur., 2002). Ralston, Zazove i Gorenflo (1996) ispitali su 165 liječnika opće prakse o njihovoj percepciji komunikacije s pacijentima, stavovima o pacijentima te o znanju o gluhoći. Liječnici su po slučaju bili podijeljeni u dvije skupine $\mathrm{i}$ ispunjavali identičan upitnik. Jedna skupina liječnika ispunjavala je upitnik u kojem ih se pitalo o njihovim pacijentima općenito, a druga skupina liječnika ispunjavala je upitnik u kojem ih se pitalo o njihovim gluhim pacijentima. Rezultati su pokazali da se liječnici iz dvije skupine nisu razlikovali po znanju o gluhoći, ali su se statistički značajno razlikovali po stavovima prema pacijentima. Liječnici koji su ispunjavali upitnik o gluhim pacijentima iskazali su veći stupanj nelagode u radu s pacijentima, stav da im pacijenti u manjoj mjeri vjeruju te stav da se pacijenti lakše naljute tijekom komunikacije. Ubido, Huntington i Warburton (2002) proveli su kvalitativno istraživanje na skupini gluhih žena o njihovim iskustvima u zdravstvenoj skrbi. Prepoznat je niz problema s kojima se te pacijentice suočavaju, npr. zdravstveni djelatnici govore a da ih ne gledaju u lice ili govore nerazumljivo, što gluhim i nagluhim pacijentima otežava mogućnost očitavanja izgovorenog s usana. Cooper, Mason i Mason (2003) ispitali su više od 300 stručnjaka za mentalno zdravlje o poznavanju činjenica o gluhoći, prethodnim kontaktima s gluhim osobama i njihovim stavovima prema gluhim pacijentima. Sudionike se pitalo o količini prethodnih kontakata te o njihovu zadovoljstvu tim kontaktom, ovisno o 
tome je li gluha/nagluha osoba bila prijatelj, rođak, pacijent, kolega nižeg, istog ili višeg socijalnog ranga u odnosu na sudionika. Pokazalo se da znanje o gluhoći nije bilo povezano sa stavovima prema gluhim pacijentima, kao ni količina kontakta s gluhim osobama. Međutim, kad je kontrolirana vrsta prethodnog kontakta, dobiveni su zanimljivi rezultati. Prethodni kontakt s gluhim pojedincem koji je bio istog ili višeg socijalnog statusa u odnosu na stručnjaka za mentalno zdravlje bio je značajno povezan s pozitivnim stavovima prema gluhim pacijentima općenito. Dob sudionika pokazala se također značajnom varijablom, pa su mlađi stručnjaci za mentalno zdravlje imali pozitivniji stav prema gluhim pacijentima nego stariji. Ispitujući stavove 200 grčkih medicinskih sestara Velonaki i sur. (2015) dobili su rezultate koji su pokazali pozitivnu povezanost između percipirane samoefikasnosti medicinskih sestara i bihevioralnog aspekta stava prema gluhim pacijentima. Sestre niže samoefikasnosti više su izbjegavale raditi s gluhim pacijentima.

Suvremeni međunarodni standardi odnosa prema gluhim i nagluhim osobama uključuju temeljna načela ljudskih prava, među kojima je i načelo nediskriminacije na svim razinama. $U$ obrazovnom sustavu, u kojem se dugi niz godina provodi integracija gluhe i nagluhe djece u redovnim školama, ona se sustavno istražuje, za razliku od zdravstvenog sustava, gdje su aspekti komunikacije i rada s ovom skupinom pacijenata do sada manje istraženi. Kao važan korelat stava učenika i nastavnika u školama vrlo se često spominje mogućnost kontakta s članovima zajednice gluhih i nagluhih osoba (Hung, 2005). No, De Laat i sur. (2013) ističu kako nije dovoljan bilo kakav kontakt. Za formiranje stava presudna je kvaliteta prethodnog kontakta s gluhim pojedincem, a pozitivnije prethodno iskustvo pridonosi formiranju pozitivnijeg stava. Za formiranje stavova učenika veliku važnost ima i percepcija načina ponašanja koja je prihvatljiva skupini vršnjaka kojoj pripadaju. Ako se radi o stavu prema gluhom vršnjaku iz razreda, percepcija standarda ponašanja i razrednog ozračja u odnosu na integraciju gluhog učenika, važan je korelat stava. Hung (2005) je na velikom uzorku ispitao stavove čujućih učenika od šestog do dvanaestog razreda američkih škola te su rezultati pokazali da su njihovi stavovi uglavnom pozitivni. Najpozitivnije stavove imali su učenici srednjoškolske dobi. Stavovi učenika koji su imali pozitivniju percepciju razrednog ozračja povezanog $\mathrm{s}$ integracijom gluhih i nagluhih učenika te posljedica integracije za njih osobno $\mathrm{i}$ njihov razred u cjelini, imali su i pozitivnije stavove.

Istraživanja stavova prema gluhim i nagluhim učenicima i njihovoj integraciji u redovne škole u Hrvatskoj se provode tridesetak godina, gotovo jednako dugo koliko i sama integracija. Najviše se istražuju stavovi roditelja čujućih učenika i nastavnika, a nešto manje i samih učenika (Mustać, 1977; Stančić, 1982; Oberman-Babić, 1987; Uzelac, 1989; Radovančić, 1994 i 1985; Kiš-Glavaš i Pantić, 2002; Bosnar i Bradarić-Jončić, 2006 i 2008; Dulčić i Bakota, 2008; Kunac, 2015). U dostupnim istraživanjima u ispitivanjima stavova učenika, sudionici istraživanja su najčešće učenici osnovnih škola, dok su istraživanja stavova učenika srednjoškolske dobi rijetka. Kozjak Mikić, Šaban i Ivasović (2017) provele su program senzibiliziranja 
za potrebe gluhih/nagluhih vršnjaka u razredima gdje su ti učenici bili integrirani. Ispitale su stavove prema njima prije i poslije provedbe programa, no provedeni program nije pridonio promjeni.

Kako su dosadašnja istraživanja pokazala, stavovi su relativno trajni i ne mijenjaju se lako, stoga je važno istražiti i potaknuti razvoj pozitivnih stavova prema gluhima i nagluhima, osobito kod budućih zdravstvenih djelatnika. Ako je kvaliteta prethodnog kontakta s gluhima značajna za kasnije stavove (De Laat i sur., 2013), pozitivan stav formiran kod učenika koji se školuju za zanimanja u zdravstvu mogao bi pridonijeti boljem razumijevanju i kvalitetnijoj komunikaciji s gluhim pacijentima u budućnosti, što se u dosadašnjim istraživanjima pokazalo nedostatnim. Predrasude o gluhim osobama, nepoznavanje načina komuniciranja s osobama s teškoćama sluha i nerazumijevanje kulturološkog aspekta gluhoće, dovodi zdravstvene djelatnike u situaciju da troše previše vremena pokušavajući komunicirati, a manje se bave samim zdravstvenim problemom osobe (Pelčić, 2007). Ova činjenica utječe na zadovoljstvo pacijenta, a potencijalno i na ishod zdravstvene intervencije. Frković (2006) je provela ispitivanje na uzorku od 17 gluhih i nagluhih žena u dobi od 23 do 50 godina o njihovim iskustvima komunikacije s medicinskim osobljem tijekom porođaja. Tek je trećina sudionica smatrala da je komunikacija s liječnikom tijekom njihova porođaja bila dobra. Pribanić i Milković (2016) ispitivale su kvalitetu pružanja zdravstvenih usluga osobama oštećena sluha u Hrvatskoj iz perspektive gluhih pacijenata širokog raspona dobi. Ispitano je 65 gluhih osoba, od kojih je $65 \%$ izjavilo je da je imalo teškoća u komunikaciji prilikom traženja zdravstvenih usluga, a oko $50 \%$ ih je izjavilo da su se osjećali nelagodno u situaciji kad nisu bili sigurni jesu li dobro razumjeli što zdravstveni djelatnik govori, a neugodno im je bilo više puta tražiti da im se ponovi. Uviđajući potrebu za unaprjeđivanjem kvalitete komunikacije zdravstvenih djelatnika s gluhim osobama, Hrvatski zavod za javno zdravstvo 2017. godine organizirao je edukaciju za zdravstvene djelatnike te objavio brošuru o specifičnostima zdravstvene skrbi osoba s invaliditetom. U brošuri se obrađuju i specifičnosti gluhih i nagluhih osoba i načela dobre zdravstvene komunikacije s ovom skupinom pacijenata. Pored osoba s urođenom gluhoćom, s obzirom na starenje stanovništva $\mathrm{RH}$, može se očekivati sve veći broj pacijenata s oslabljenim sluhom, pa je ovo pitanje tim važnije.

S obzirom na sve navedeno, kao i narav budućeg posla sudionika ovog istraživanja koji se školuju upravo za zdravstvena zanimanja, vrijedno je istražiti njihove stavove prema gluhima. Cilj istraživanja bio je ispitati emocionalni aspekt stava polaznika zdravstvenih škola prema gluhim i nagluhim vršnjacima te je definirano nekoliko problema istraživanja:

1. Ispitati percepciju bliskosti s gluhim i nagluhim učenicima ovisno o tome ima li škola integrirane gluhe/nagluhe učenike ili nema.

2. Provjeriti postoje li razlike u percipiranoj bliskosti u odnosu na gluhe/nagluhe učenike s obzirom na to integrira li škola gluhe i nagluhe učenike ili ne, spol sudi- 
onika, učestalost prethodnih dobrovoljnih kontakta s gluhim osobama te percepciju razrednog ozračja povezanu s integracijom gluhih.

\section{METODA}

\section{Sudionici i postupak istraživanja}

U istraživanju je sudjelovalo ukupno 328 učenika drugih razreda srednje škole u dobi od 15,5 do 16,5 godina, od čega 270 djevojaka (82,3\%) i 58 dječaka $(17,7 \%)$. Ukupno 183 učenika $(55,8 \%)$ pohađala su školu koja integrira gluhe i nagluhe učenike, od čega je njih $46(25,1 \%)$ pohađalo dva razreda u kojima su bili gluhi učenici. To je razlog zašto su sudionici bili upravo učenici drugih razreda; 145 sudionika $(44,2 \%)$ pohađalo je škole u kojima nije bilo integriranih gluhih učenika. Sudionici su bili polaznici iz devet različitih programa zdravstvenih usmjerenja u tri zagrebačke srednje škole, a njihova prebivališta bila su u različitim dijelovima Hrvatske.

Podatci su prikupljeni uz prethodnu suglasnost ravnatelja škola za provedbu istraživanja i pristanak roditelja. Roditelji su dali usmeni pristanak za provedbu istraživanja na roditeljskim sastancima. Učenicima je ukratko objašnjena svrha istraživanja te pročitana uputa o načinu popunjavanja podataka. Primjena upitnika trajala je dvadesetak minuta, bila je anonimna i provedena je tijekom satova razrednih odjela ili satova Zdravstvene psihologije.

\section{Instrumentarij}

U radu su korištene dvije skale iz Inventara inkluzije gluhih i nagluhih učenika (engl. Inclusion of Deaf or Hard of Hearing Students Inventory, H. L. Hung; 2005), koji je, uz dopuštenje autorice, adaptiran i preveden na hrvatski.

1. Percepcija bliskosti mjerena je Skalom percipirane bliskosti Likertova tipa. Skala ima osam čestica kojima se iskazuje stupanj bliskosti u druženju, odnosima i kontaktima s gluhim i nagluhim učenicima. Sudionici su odgovarali odabirom jedne od ponuđenih skalnih točaka (u potpunosti se ne slažem; ne slažem se; nisam siguran, donekle se ne slažem; nisam siguran, donekle se slažem; slažem se; u potpunosti se slažem). Rezultat je iskazan kao kompozitna varijabla dobivena zbrajanjem rezultata na svim skalnim česticama, uz prethodno izmijenjen smjer pojedinih čestica prema ključu za odgovore. Veći rezultat znači veću iskazanu bliskost, odnosno pozitivniji stav. Pouzdanost skale izražena Cronbach alfa indeksom bila je vrlo dobra i iznosi 0,80 .

2. Podatci o percepciji razrednog ozračja povezanog s integracijom gluhih prikupljeni su Skalom razrednog ozračja Likertova tipa od jedanaest čestica. Sudionici su odgovarali odabirom jedne od šest ponuđenih skalnih točaka čije su vrijednosti bile iste kao kod Skale percipirane bliskosti. S obzirom na rezultate koje u istraži- 
vanju navodi autorica skale (Hung, 2005), provedena je analiza glavnih komponenti Kaiser-Oblimin normalizacijom. Prethodno je provjerena prikladnost podataka za faktorsku analizu. U korelacijskoj matrici je bilo mnogo koeficijenata većih od 0,3, vrijednost KMO (Kaiser-Meyer-Olkin) pokazatelja bila je 0,85 , a Barlettov test sfericiteta bio je statistički značajan $(891.20, \mathrm{df}=55, \mathrm{p}<0,000)$, što je uputilo na opravdanost provedbe faktorske analize (Pallant, 2011). Analizom glavnih komponenti izdvojena su dva glavna faktora čije su karakteristične vrijednosti veće od 1 $(3,95$ i 1,25$)$ i koji zajedno objašnjavaju $48 \%$ ukupne varijance. Doprinos prve komponente je $36 \%$, a druge $12 \%$. Provedena je Oblimin rotacija te je utvrđena struktura komponenti. Usporedbom dobivenih rezultata s rezultatima autorice originalne skale, ustanovljena je njihova podudarna struktura. Formirane su dvije subskale koje smo nazvali Osobni i socijalni aspekt (sedam čestica) i Aspekt razrednih aktivnosti (četiri čestice) koje su korištene u daljnjoj analizi rezultata. Rezultat je na ove dvije subskale iskazan kao kompozitna varijabla te izračunat zbrajanjem brojeva pridruženih odabranim skalnim točkama, uz prethodno izmijenjen smjer pojedinih čestica prema ključu za odgovore. Veći rezultat označava pozitivniju percepciju. Pouzdanost subskale Osobni i socijalni aspekt izražena Cronbach alfa indeksom bila je 0,75 , a pouzdanost subskale Aspekt razrednih aktivnosti bila je 0,69 , što je vrlo dobro s obzirom na mali broj čestica.

3. Podatci o učestalosti prethodnih dobrovoljnih kontakata s gluhim i nagluhim osobama dobiveni su odgovorima na tri pitanja: Koliko često srećeš gluhe i nagluhe osobe?; Koliko često susrećeš i dobrovoljno kontaktiraš s učenicima koji su gluhi ili nagluhi?; Koliko često u svome razredu dobrovoljno kontaktiraš s učenicima koji su gluhi ili nagluhi?. Učenici su kao odgovor na svako od navedenih pitanja birali jedan od pet ponuđenih odgovora (svakodnevno ili gotovo svakodnevno; jednom tjedno; 1-3 puta mjesečno; 1-10 puta u godini; nikad ili gotovo nikad). Prilikom obrade podataka veći broj pridružen je odgovoru koji upućuju na češći prethodni dobrovoljni kontakt. Ukupan rezultat predstavlja kompozitnu varijablu odgovora na ovim česticama.

\section{REZULTATI}

Kako bismo odgovorili na prvi postavljeni problem, izračunati su osnovni deskriptivni podatci za sve sudionike i podatci o izgledu raspodjela rezultata (Tablica 1). S obzirom na broj skalnih čestica na Skali percipirane bliskosti, rezultati se mogu kretati unutar totalnog raspona od 8 do 48. Prosječan rezultat svih sudionika je 40,59, što ukazuje na visoku iskazanu bliskost. Rezultati na skali Razrednog ozračja-osobni i socijalni aspekt mogli bi biti u totalnom rasponu od 7 do 42. Prosječan je rezultat 30, što upućuje na relativno pozitivnu percepciju. Rezultati na skali Razredno ozračje-aspekt razrednih aktivnosti mogli bi se kretati u totalnom rasponu od 4 do 24 . Postignut je prosječan rezultat 18 , što također upućuje na relativno 
Tablica 1. Osnovni deskriptivni podatci i podatci o izgledu raspodjele rezultata za korištene varijable $(N=328)$

\begin{tabular}{lcccc}
\hline & $\begin{array}{c}\text { Percipirana } \\
\text { bliskost }\end{array}$ & $\begin{array}{c}\text { Razredno ozračje: } \\
\text { Osobni i socijalni } \\
\text { aspekt }\end{array}$ & $\begin{array}{c}\text { Razredno ozračje: } \\
\text { Aspekt razrednih } \\
\text { aktivnosti }\end{array}$ & $\begin{array}{c}\text { Prethodni } \\
\text { dobrovoljni kontakt }\end{array}$ \\
\hline$M$ & 40,59 & 30 & 18 & 6,71 \\
$S D$ & 5,77 & 4,86 & 3,63 & 4,09 \\
$T R$ & $8-48$ & $7-42$ & $4-24$ & $3-15$ \\
OR & $21-48$ & $12-42$ & $7-24$ & $3-15$ \\
$K-S$ & $2,04^{*}$ & $1,70^{*}$ & $2,12^{*}$ & $3,87^{*}$ \\
asimetrija & $-1,02$ & $-0,58$ & $-0,61$ & 0,94 \\
spljoštenost & 0,86 & 0,76 & $-0,08$ & $-0,50$ \\
\hline
\end{tabular}

$K-S=$ Kolomgorov- Smirnovljev test normaliteta raspodjele; ${ }^{*} p<0,005 ; T R=$ totalni raspon rezultata; $O R=$ opaženi raspon rezultata

pozitivnu percepciju sudionika. U skladu s time su i podatci o karakteristikama raspodjele rezultata koji pokazuju da se one razlikuju statistički značajno od normalne raspodjele u smjeru viših (pozitivnijih) rezultata, što nije neočekivano s obzirom na sudionike, predmet mjerenja i veličinu uzorka (Pallant, 2011). Na skali prethodnog dobrovoljnog kontakta bilo je moguće postići rezultate u totalnom rasponu od 3 do 15 bodova, kakav je i opaženi raspon rezultata. Prosječan rezultat od 6,71 upućuje na relativno malo prethodnih dobrovoljnih kontakata s gluhim i nagluhim osobama.

Podatci o izgledu raspodjela rezultata upućuju na relativno male asimetrije i spljoštenosti, no sve se distribucije rezultata statistički značajno razlikuju od normalne. Stoga su u daljnjoj obradi rezultata korišteni neparametrijski statistički postupci. Kako bi se provjerila razlika u percipiranoj bliskosti ovisno o tome integrira li škola gluhe učenike ili ne i ovisno o spolu sudionika, korišten je Mann-Whitney U test kao neparametrijska alternativa t-testu nezavisnih uzoraka.

Sudionici su prvo podijeljeni po tome ima li škola integrirane gluhe/nagluhe učenike ili nema te je za svaku tako definiranu skupinu izračunat medijan rezultata. Medijani rezultata na Skali percipirane bliskosti dviju skupina sudionika vrlo su slični, što je suprotno očekivanjima. Nije nađena razlika u percipiranoj bliskosti s gluhim vršnjacima, ovisno o tome integrira li ih škola u redovne razrede ili ne. Druga podjela sudionika rađena je na osnovi spola te su i za te dvije skupine izračunati medijani njihovih rezultata. Razlika u percipiranoj bliskosti ovisno o spolu sudionika statistički je značajna $(U=4357.000 ; Z=-5,231 ; p=0,000)$. Djevojke imaju višu percipiranu bliskost u odnosu na dječake. Medijan rezultata djevojaka je 42, a medijan rezultata koje su postigli dječaci je 38. Izračunata je i veličina učinka $(r=0,02)$, koja je ipak pokazala zanemarivo mali učinak. Vrijednost $r$ izračunata je kao Z/ kvadratni korijen od N (Pallant, 2011). 
Tablica 2. Razlike u percipiranoj bliskosti s gluhima ovisno o integraciji gluhih učenika u školi i spolu sudionika $(N=328)$

\begin{tabular}{|c|c|c|c|}
\hline \multicolumn{2}{|c|}{ Integrirani učenici u školi } & \multicolumn{2}{|c|}{ Spol sudionika } \\
\hline $\mathrm{Da}$ & $\mathrm{Ne}$ & Dječaci & Djevojke \\
\hline $\begin{array}{c}N=183(55,8 \%) \\
C=41\end{array}$ & $\begin{array}{c}N=145(44,2 \%) \\
C=42\end{array}$ & $\begin{array}{c}N=58(17,7 \%) \\
C=38\end{array}$ & $\begin{array}{c}N=270(82,3 \%) \\
C=42\end{array}$ \\
\hline \multicolumn{2}{|c|}{$\begin{array}{c}U=11850,00 \\
Z=-1,408 ; p=0,159\end{array}$} & \multicolumn{2}{|c|}{$\begin{array}{c}U=4357,000 \\
Z=-5,231 ; p=0,000^{* *} ; r=0,02\end{array}$} \\
\hline
\end{tabular}

${ }^{* *} p<0,001, C=$ medijan rezultata; $U=$ Mann-Whitney $\mathrm{U}$ test; $r=$ veličina učinka

Kako bismo provjerili ima li razlika u percipiranoj bliskosti s obzirom na učestalost prethodnog dobrovoljnog kontakta te percepciju razrednog ozračja, također su izračunati Mann-Whitney U testovi. Za potrebe ovih analiza, nezavisne varijable podijeljene su u kategorije (Tablica 3). U kategoriji 1 su niži rezultati - učenici koji manje pozitivno percipiraju razredno ozračje u odnosu na osobne i socijalne posljedice integracije i na razredne aktivnosti te učenici koji su imali manje prethodnih dobrovoljnih kontakata s gluhima. U kategoriji 2 su viši rezultati na svakoj od ovih varijabli.

Izračunati su Spearmanovi koeficijenti povezanosti. Varijable razrednog ozračja statistički su značajno povezane $(p<0,001) \mathrm{s}$ varijablom percipirane bliskosti te međusobno, iako se radi o relativno niskim koeficijentima (bliskost- $F 1=0,36^{* *}$, bliskost- $F 2=0,32 * * ; F 1-F 2=0,31 * *)$. Tablica 4 pokazuje rezultate provedenih Mann-Whitney U testova. Učenici koji imaju pozitivniju percepciju razrednog ozračja s obzirom na posljedice integracije gluhih na osobni i socijalni život unutar razreda te pozitivniju percepciju posljedica integracije na razredne aktivnosti, iskazuju veću percipiranu bliskost s gluhima. Izračunate su veličine učinka $(r)$, koje su se pokazale vrlo malima u oba slučaja. To pokazuje da su razlike, iako statistički značajne, zapravo vrlo male, na što upućuju i rezultati medijana. Odnos kontakta i

Tablica 3. Frekvencije rezultata nezavisnih varijabli podijeljenih po kategorijama $(N=328)$

\begin{tabular}{lcc}
\hline Varijabla & Kategorija 1 & Kategorija 2 \\
\hline Razredno ozračje- osobni i socijalni aspekt (F1) & $<=31$ & $32+$ \\
& $N=188(57,3 \%)$ & $N=140(42,7 \%)$ \\
Razredno ozračje- aspekt razrednih aktivnosti (F2) & $<=18$ & $19+$ \\
& $N=166(50,6 \%)$ & $N=162(49,4 \%)$ \\
Prethodni dobrovoljni kontakt & $<=5$ & $6+$ \\
& $N=182(55,5 \%)$ & $N=146(44,5 \%)$ \\
\hline
\end{tabular}


Tablica 4. Razlike u percipiranoj bliskosti s gluhima ovisno o percepciji razrednog ozračja s obzirom na osobni i socijalni aspekt te aspekt razrednih aktivnosti $(N=328)$

\begin{tabular}{|c|c|c|c|}
\hline \multicolumn{2}{|c|}{$\begin{array}{c}\text { Razredno ozračje } \\
\text { - osobni i socijalni aspekt }\end{array}$} & \multicolumn{2}{|c|}{$\begin{array}{c}\text { Razredno ozračje } \\
\text { - aspekt razrednih aktivnosti }\end{array}$} \\
\hline manje pozitivno & više pozitivno & manje pozitivno & više pozitivno \\
\hline$C=40$ & $C=44$ & $C=40$ & $C=43$ \\
\hline $\begin{array}{r}U= \\
Z=-6,337 ;\end{array}$ & $* * ; r=0,02$ & \multicolumn{2}{|c|}{$\begin{array}{c}U=8195.000 \\
Z=-5,781 ; p=0,000^{* *} ; r=0,02\end{array}$} \\
\hline
\end{tabular}

${ }^{* *} p<0,001, C=$ medijan rezultata; $U=$ Mann-Whitney $\mathrm{U}$ test; $r=$ veličina učinka

percipirane bliskosti provjeravan je korištenjem kompozitne varijable kontakt (učestalost kontakta), no nije dobivena značajna povezanost.

Kolmogorov-Smirnovljev test normaliteta raspodjele dosta je strog test i bilježi i minimalna odstupanja od normaliteta, distribucije svih rezultata odstupaju od normalne raspodjele $\mathrm{u}$ istome smjeru (negativno su asimetrične), a broj sudionika istraživanja relativno je velik. To opravdava i korištenje parametrijskih postupaka koji su veće statističke snage. Stoga su rezultati provjereni i parametrijskim postupcima. Oni su potvrdili prethodno navedene rezultate dobivene neparametrijskim postupcima.

Dostupni rezultati o povezanosti kontakta i stavova prema gluhima nisu konzistentni. Stoga je provjeren i odnos pojedinačnih varijabli kontakta s percipiranom bliskosti Kruskal-Wallis testom (neparametrijska alternativa jednofaktorskoj analizi varijance različitih grupa). Ni ovi rezultati nisu pokazali značajnu razliku u percipiranoj bliskosti, ovisno o količini (učestalosti) kontakata (Tablica 5).

Tablica 5. Razlike u percipiranoj bliskosti s gluhima ovisno o varijablama dobrovoljnog kontakta $(N=328)$

\begin{tabular}{lcc}
\hline Količina (učestalost) kontakata & Prethodni kontakt općenito & Prethodni kontakt u školi \\
\hline nikad ili gotovo nikad & $90(27,4 \%)$ & $190(57,9 \%)$ \\
1-10 puta godišnje & $81(24,7 \%)$ & $16(4,9 \%)$ \\
$1-3$ puta mjesečno & $44(13,4 \%)$ & $18(5,5 \%)$ \\
jednom tjedno & $34(10,4 \%)$ & $39(11,9 \%)$ \\
svakodnevno ili gotovo svakodnevno & $79(24,1 \%)$ & $65(19,8 \%)$ \\
\cline { 2 - 3 } & $\chi^{2}=2,352 ; d f=4$ & $\chi^{2}=3,345 ; d f=4$ \\
& $p=0,671$ & $p=0,502$ \\
\hline
\end{tabular}

$\chi^{2}=$ Kruskal-Wallis test; $d f=$ stupanj slobode 
Odnosi varijabli provjereni su dodatno na poduzorku učenika koji su pohađali školu s integracijom $(N=183)$. Rezultati su uglavnom potvrdili odnose varijabli dobivene na svim sudionicima. Dobivena je statistički značajna razlika u percipiranoj bliskosti mladića $(C=39)$ i djevojaka $(C=41) ; U=1644,500 ; Z=-3,440$; $\left.p=0,000^{* *}\right)$. Djevojke imaju pozitivniju percepciju, a veličina tog učinka $(r=$ $0,254)$ je srednje velika. Učenici koji imaju pozitivniju percepciju razrednog ozračja s obzirom na posljedice integracije gluhih za osobni i socijalni život unutar razreda $(C=43,50)$ u odnosu na skupinu s manje pozitivnom percepcijom $(C=40)$ imaju statistički višu percepciju bliskosti, a učinak je srednje velik $(U=2115,000 ; Z=$ $\left.-4,723 ; p=0,000^{* *} ; \mathrm{r}=0,349\right)$. Učenici koji imaju pozitivniju percepciju posljedica integracije na razredne aktivnosti $(\mathrm{C}=43) \mathrm{u}$ odnosu na skupinu s manje pozitivnom percepcijom $(C=40)$ imaju statistički višu percepciju bliskosti, a učinak je srednje velik $\left(U=2611,500 ; Z=-4,069 ; p=0,000^{* *} ; r=0,301\right)$.

Nije nađena razlika u percipiranoj bliskosti ovisno o količini (broju) kontakta kad je varijabla kontakt promatrana kao kompozitna. Provjerom odnosa pojedinačnih varijabli kontakta s percipiranom bliskost, nisu nađene statističke razlike u percipiranoj bliskosti ovisno o količini kontakata kad je nezavisna varijabla bio općeniti prethodni kontakt s gluhim osobama $\left(\chi^{2}=5,626 ; d f=4 ; p=0,229\right)$ i dobrovoljni kontakt s gluhim vršnjacima u školi $\left(\chi^{2}=2,205 ; d f=4 ; p=0,698\right)$.

Kad je analiziran odnos varijable bliskosti i varijable prethodni dobrovoljni kontakt unutar razreda, dobivena je značajna razlika ovisno o učestalosti kontakata $\left(\chi^{2}=17,950 ; d f=3 ; p=0,000^{* *}\right)$. Učenici koji u svojim razredima imaju integrirane gluhe vršnjake u većini izjavljuju da s njima kontaktiraju svakodnevno ili gotovo svakodnevno (32 ili 69,5\%), manji dio (12) jednom-tri puta tjedno, a svega dvoje je navelo da kontaktira jednom do tri puta mjesečno. Među njima nitko nije naveo da s gluhim vršnjacima kontaktira jednom do 10 puta godišnje. Skupina učenika koji nemaju gluhe u svome razredu na skali percipirane bliskosti ima medijan $C=42$, medijan skupine koja u svome razredu kontaktira s gluhim vršnjacima jednom do tri puta mjesečno je $C=28$, skupine koja kontaktira jednom tjedno je $C=38$. Medijan rezultata na skali percipirane bliskosti učenika koji s gluhim vršnjacima kontaktiraju svakodnevno je $C=40$.

\section{RASPRAVA}

Inozemna, kao i malobrojna hrvatska istraživanja, pokazala su da u traženju i primanju zdravstvenih usluga gluhe i nagluhe osobe imaju poteškoća. S obzirom na izmijenjenu mogućnost korištenja zdravstvenih usluga gluhih pacijenata i komunikacijske poteškoće, često se događa da zdravstveni radnici previše vremena potroše pokušavajući komunicirati s njima, što smanjuje vrijeme bavljenja samim zdravstvenim problemom (Frković, 2006; Pribanić i Milković, 2016). Ovim se istraživanjem želio ispitati emocionalni aspekt stava polaznika u zdravstvenim programima 
prema gluhim i nagluhim učenicima i njihovoj integraciji. Očekivali smo da će sudionici iskazati visoku razinu percipirane bliskosti s gluhima i nagluhima s obzirom na to da se radi o učenicima koji su odabrali zdravstvena zanimanja. Moglo bi se očekivati da oni u prosjeku imaju visoku empatičnost, ali i toleranciju različitosti. Dobivene su negativno asimetrične distribucije rezultata, koje su pokazale da je percipirana bliskost relativno visoka, odnosno rezultati su u skladu s očekivanjima i rezultatima ranijih inozemnih istraživanja (Nunes, Pretzlik i Olsson, 2000; Hung, 2005). U istraživanju su bili uključeni polaznici iz zdravstvenih škola koje su se razlikovale s obzirom na to integriraju li gluhe i nagluhe učenike ili ne. Prema hipotezi kontakta (Allport, 1954), stavovi prema članovima bilo kakve manjinske skupine povezani su s mogućnošću kontakta s njima. Dosadašnja istraživanja o tome nisu dala konzistentne rezultate. Dimoski, Eminović, Stojković i Stanimirović (2013) ispitujući stavove prema gluhim osobama djece i njihovih roditelja koji su živjeli u blizini škole za gluhe, pokazali su da je s pozitivnijim stavovima povezan čak i sasvim površan kontakt. U nekim se istraživanjima provedenim s učenicima pokazalo da kontakt sam po sebi nije značajan za stav prema gluhima (Cooper i sur., 2003., De Laat i sur., 2013). Stoga smo željeli provjeriti postoje li razlike u percipiranoj bliskosti s obzirom na to ima li škola integrirane gluhe učenike, uz očekivanje da će u školama koje integriraju gluhe u redovne razrede stavovi biti pozitivniji. No, rezultati gotovo uopće nisu bili u skladu s očekivanjima. Razlike u percepciji bliskosti nisu se pokazale statistički značajnima bez obzira da li škola integrira gluhe učenike ili ne, što je u skladu s rezultatima Coopera i sur. (2003) i De Laata i sur. (2013). U navedenim su istraživanjima autori zaključili kako je za stav prema gluhim osobama općenito bitna kvaliteta prethodnog kontakta, odnosno zadovoljstvo prethodnim kontaktima s gluhim/nagluhim pojedincima. To je varijabla koja u ovome istraživanju nije u potpunosti kontrolirana. Prikupljeni su podatci o prethodnim dobrovoljnim kontaktima sudionika s gluhim pojedincima, s pretpostavkom da bi dobrovoljnost kontakta mogla biti povezana s njegovom višom kvalitetom. Međutim, sudionici nisu odgovarali na pitanje koliko su bili zadovoljni prethodnim kontaktima s gluhim/nagluhim osobama. Na zadovoljstvo kontaktom mogle su utjecati i varijable poput karakteristika ličnosti sudionika, ali i gluhog/nagluhog učenika i kvalitete njihova kontakta prema čujućim vršnjacima. Pored toga variranje rezultata znatno je smanjeno jer su rezultati na Skali percipirane bliskosti u obje skupine sudionika općenito visoki. Radi se i o vrlo malom broju integriranih učenika (njih 4), s kojima je samo dio ispitanih učenika bio u neposrednom kontaktu jer su u istraživanju sudjelovali i učenici koji su u svojim razredima imali integrirane gluhe učenike $\mathrm{i}$ oni koji ih nisu imali.

Jedno od istraživačkih pitanja bilo je i razlikuju li se u percipiranoj bliskosti djevojke i dječaci, s očekivanjem da će djevojke pokazati pozitivnije stavove. Djevojke su iskazale nešto višu razinu percipirane bliskosti, koja je bila statistički značajna, ali je razlika zapravo vrlo mala. Na rezultat je mogao utjecati omjer sudionika po 
spolu jer je djevojaka je bilo znatno više (82\%). Viša percepcija bliskosti kod djevojaka nađena je i u poduzorku sudionika iz škole koja integrira gluhe učenike. Dobiveni je rezultat u skladu s rezultatom autorice korištenog upitnika (Hung, 2005). U njezinu su istraživanju djevojke također iskazale pozitivnije stavove prema gluhima u odnosu na dječake, ali je ta razlika, iako značajna, zapravo bila vrlo mala, kako je to dobiveno i u ovome istraživanju.

S obzirom na važnost vršnjaka za formiranje stavova u adolescenciji ispitana je povezanost percepcije razrednog ozračja i prethodnih dobrovoljnih kontakata s percipiranom bliskošću s gluhim učenicima. Suprotno početnim očekivanjima, pokazalo da prethodni kontakt nije značajno povezan s percepcijom bliskosti s gluhim/ nagluhim vršnjacima (osim unutar razreda), bez obzira je li varijabla kontakta analizirana kao kompozitna ili na razini pojedinačnih varijabli kontakta. Moguće je da je takav rezultat dobiven jer je među sudionicima velik broj učenika koji nisu nikada ili gotovo nikada bili u bilo kakvoj komunikaciji s gluhom ili nagluhom osobom ili je to bilo vrlo rijetko. Nakon što je povezanost kontakta i percipirane bliskosti analizirana samo na skupini sudionika koji pohađaju školu koja integrira gluhe učenike, nađena je statistički značajna razlika između onih koji nemaju priliku kontaktirati s gluhima u svojim razredima i onih koji izjavljuju da dobrovoljni kontakt s njima ostvaruju svakodnevno. S obzirom na veliku razliku u broju učenika koji uopće imaju integrirane gluhe vršnjake u svom razredu i onih koji ih nemaju, pa $i$ ne mogu ostvarivati toliko čest svakodnevni dobrovoljni kontakt, treba biti oprezan u tumačenju ovih rezultata. Trend rezultata pokazuje da učenici koji ostvaruju veći broj dobrovoljnih kontakata imaju veću percepciju bliskosti s gluhima. Zanimljivo je da je medijan rezultata učenika koji u svom razredu nemaju integrirane gluhe najveći, što nije očekivano. Socijalni razvoj gluhih i nagluhih učenika je otežan zbog značajnih komunikacijskih barijera koje otežavaju stvaranje bliskih veza čujućih učenika s njima. Gluhi učenik uglavnom ne razumije govor vršnjaka dovoljno da brzo shvati kolokvijalne izraze, šale i neobavezne razgovore, ironiju i sve ono što zapravo pripada nepisanom "jezičnom kodu” unutar vršnjačke grupe. Gluhi učenik ne može u jednakoj mjeri sudjelovati u vršnjačkim razgovorima i aktivnostima, što dovodi do određene razine isključenosti iz vršnjačke grupe.

Percepcija razrednog ozračja u odnosu na integraciju gluhih i nagluhih učenika $\mathrm{u}$ redovne škole promatrana je kroz rezultate na dvije formirane subskale - Osobni i socijalni aspekt integracije i Aspekt razrednih aktivnosti. Učenici koji imaju pozitivniju percepciju razrednog ozračja s obzirom na posljedice integracije gluhih za osobni i socijalni život unutar razreda te pozitivniju percepciju posljedica integracije na razredne aktivnosti, iskazuju veću percipiranu bliskost s gluhima, što je potvrđeno i na poduzorku učenika škole koja integrira gluhe. Rezultati su u skladu s očekivanjima i rezultatima dobivenim u istraživanju na američkim učenicima (Hung, 2005). 


\section{ZAKLJUČAK}

Rezultati istraživanja su pokazali da je emocionalni aspekt stava učenika medicinskih škola - budućih zdravstvenih djelatnika prema gluhima i nagluhima pozitivan. To je dobra osnova za usvajanje znanja o specifičnostima komunikacije s gluhim pacijentima, što bi u budućem radu moglo pomoći preciznijoj i kvalitetnijoj komunikaciji, a time i boljoj zdravstvenoj skrbi gluhih i nagluhih osoba. Na osnovi rezultata dosad provedenih istraživanja, smatra se da postoji povezanost između percepcije veće bliskosti i pozitivnijih procjena i stavova prema gluhima. Kako bi se pozitivni stavovi dodatno potakli, kroz kurikulume medicinskih škola trebalo bi omogućiti upoznavanje uspješnih gluhih osoba, osobito mladih, koji bi učenicima bili pozitivan model, ponuditi učenje osnova znakovnog jezika, omogućiti što češće međusobne kontakte gluhih i čujućih učenika i slično.

Potrebno je kritički se osvrnuti na provedeno istraživanje i rezultate. Istraživanje usmjereno na ispitivanje stavova prema jednom ranjivom dijelu populacije vrijedno je, ali potrebno je imati na umu njegova metodološka ograničenja. Provedeno je na prihvatljivo velikom uzorku srednjoškolaca, s kojima su u Hrvatskoj istraživanja stavova prema gluhima rijetka. Međutim, radilo se o prigodnom uzorku, a istraživanje je korelacijskog tipa, pa rezultati i zaključci imaju ograničenu vrijednost. Neki relevantni čimbenici koji su mogli imati značajan utjecaj na rezultate su neujednačen broj sudionika po spolu, nisu kontrolirane karakteristike ličnosti gluhih učenika i kvaliteta njihova odnosa prema čujućim vršnjacima i sl., što u budućim istraživanjima treba uzeti u obzir.

\section{LITERATURA}

Allport, G. (1954). The Nature of Prejudice. Cambridge: MA.: Addison-Wesley Publishing Company.

Benjak, T., Petreski, N.T., Štefančić, V., Ivanić, M., Radošević, M. i Vejzović, Z. (2017). Registar osoba s invaliditetom u RH za 2016. Zagreb: Hrvatski zavod za javno zdravstvo, Služba za javno zdravstvo Ministarstva zdravstva i socijalne skrbi.

Bosnar, B. i Bradarić- Jončić, S. (2008). Stavovi prema integraciji gluhe djece, znakovnom jeziku i uključivanju tumača za znakovni jezik u redovne vrtiće i škole. Hrvatska revija za rehabilitacijska istraživanja, 44(2), 11-30.

Bosnar, B. i Bradarić-Jončić, S. (2006). Stavovi prosvjetnih djelatnika prema uključivanju gluhe djece i mladeži u redovne škole i vrtiće. U: Hicela, I. (Ur.), Zbornik radova sa znanstveno -stručnog skupa s međunarodnom suradnjom Peti dani osnovne škole Splitsko-dalmatinske županije: Prema kvalitetnoj školi (151-164). Split: HPKZ -Ogranak Split i Filozofski fakultet Sveučilište u Splitu.

Cooper, A.E., Mason J.R. i Mason, O. (2003). Mental health professionals attitudes towards people who are deaf. Journal of Community and Applied Social Psychology, 13, 314319. 
De Laat, S., Freriksen, E. i Vervloed, M.P.J. (2013). Attitudes of children and adolescents toward persons who are deaf, blind, paralyzed, or intellectually disabled. Research in Developmental Disabilities, 34(2), 855-863.

Denmark, J. C. (1994). Deafness and mental health. London: Jessica Kingsley Publishers.

Dimoski, S., Eminović, F., Stojković, I. i Stanimirović, D. (2013). Contact with persons with hearing impairments as a correlate of children's and adults attitudes towards these persons. Croatian Journal of Education, 15(3), 611-628.

Dulčić, A. i Bakota, K. (2008). Stavovi učitelja povijesti redovnih osnovnih škola prema integriranim učenicima oštećena sluha i učenicima s poremećajima govorno-jezične komunikacije te specifičnim teškoćama u učenju. Hrvatska revija za rehabilitacijska istraživanja, 44(2), 31-50.

Frković, A. (2006). Bioetički aspekti komuniciranja s gluhim rodiljama. Gynaecologia et perinaetologia, 15(4), 187-191.

Hung, H.-L. (2005). Factors associated with the attitudes of nondisabled secondary school students toward the inclusion of peers who are deaf or hard of hearing in their general education classes. Doktorska disertacija. Ohio: The Ohio State University.

Hrvatski zavod za javno zdravstvo - Odjel za zaštitu zdravlja vulnerabilnih skupina (2017). Oštećenje sluha, gluhoća/nagluhost i savjeti za prevladavanje komunikacijskih barijera. U: Načini ostvarivanja primjerenog kontakta i specifičnosti zdravstvene skrbi za osobe $s$ invaliditetom (45-53). http://www.hzjz.hr/sluzba-javno zdravstvo/medunarodni-danosoba-s-invaliditetom- $2 /$.

Kiš-Glavaš, L. i Pantić, Z. (2002). Različitost. U: Kiš-Glavaš, L., Fulgosi-Masnjak, R. (Ur.), Do prihvaćanja zajedno: integracija djece s posebnim potrebama (45-63). Zagreb: Hrvatska udruga za stručnu pomoć djeci s posebnim potrebama - IDEM.

Kozjak Mikić, Z., Šaban, M. i Ivasović, V. (2017). Senzibiliziranje učenika srednje škole za specifične potrebe gluhih i nagluhih vršnjaka. Hrvatska revija za rehabilitacijska istraživanja, 53(2), 47-60.

Kunac, S. (2015). Razumijevanje različitosti - gluhe osobe i znakovni jezik. U: Hicela, I., Tomaš,S. (Ur.), Zbornik radova znanstveno-stručnog skupa s međunarodnom suradnjom Deseti dani osnovne škole Splitsko-dalmatinske županije: Prema kvalitetnoj školi (15-22). Split: HPKZ -Ogranak Split i Filozofski fakultet Sveučilište u Splitu, Odsjek za Učiteljski studij.

Meadow-Orlans, K. i Erting, C. (2000). Deaf people in society. U: Hindley, P., Kitson, N. (Ur.), Mental health and deafness (3-24). London: Whurr Publishers.

Mustać, V. (1977). Struktura stavova roditelja prema djeci s oštećenim sluhom koja su pod utjecajem rehabilitacijskog postupka u zavodima za rehabilitaciju slušno oštećene djece i omladine. Magistarski rad. Medicinski fakultet Sveučilišta u Zagrebu.

Nunes, T., Pretzlik, U., Olsson, J. (2000). Deaf childrens social relationships in mainstream schools. Journal of Deaf Studies and Deaf Education, 3, 123-126.

Oberman-Babić, M. (1987). Stavovi učenika redovne i specijalne škole prema odgojno obrazovnoj integraciji djece sa smetnjama u razvoju. Doktorska disertacija. Fakultet za defektologiju Sveučilišta u Zagrebu.

Pallant, J. (2011). SPSS. Beograd: Mikro knjiga. 
Pelčić G. (2007). Gluhi pacijent i zdravstvo. U: Gjuran Coha, A. (Ur.), Zbornik radova, VII. bioetički okrugli stol: Bioetički aspekti komuniciranja s gluhim pacijentima (107-114). Rijeka: Medicinski fakultet Sveučilišta u Rijeci, Katedra za društvene znanosti.

Pribanić. Lj. i Milković, M. (2016). Gluhi pacijent u sustavu zaštite zdravlja. http://www. researchgate.net/publication/289479459.

Ralston, E., Zazove, P., Gorenflo, DW. (1996). Physicians attitudes and beliefs about deaf patients. Journal of the American Board of Family Practice, 9, 167-173.

Radovančić, B. (1994). Kongruencija latentnih prostora stavova roditelja učenika s oštećenim sluhom i roditelja učenika koji čuju prema odgojno-obrazovnoj integraciji učenika s oštećenim sluhom. Defektologija, 30(1), 9-32.

Radovančić, B. (1985). Stavovi nastavnika prema odgojno-obrazovnoj integraciji djece s oštećenim sluhom. Defektologija, 21(2), 49-62.

Stančić, V. (1982). Odgojno-obrazovna integracija djece s teškoćama u razvoju. Ispitivanje objektivnih i subjektivnih pretpostavki za uključivanje djece s razvojnim smetnjama u redovne škole zagrebačke regije. Zagreb: Fakultet za defektologiju Sveučilišta u Zagrebu.

Ubido, J., Huntington, J. i Warburton, D. (2002). Inequalities in access to healthcare faced by women who are deaf. Health and social care in the community, 10(4), 247-53.

Uzelac, M. (1989). Subjektivne pretpostavke odgojno-obrazovne integracije djece s oštećenim sluhom, Magistarski rad. Fakultet za defektologiju Sveučilišta u Zagrebu.

Velonaki V.S., Ampouroglou G., Velonaki M., Dimakopoulou K., Sourtzi P., Kalokerinou A. (2015). Nurses' knowledge, attitudes and behavior toward Deaf patients. Disability and health journal, 8, 1, 109-117.

\title{
ATTITUDES TOWARDS DEAF AND HARD OF HEARING STUDENTS
}

\begin{abstract}
Summary
In addition to the stereotype of the deaf, the main causes of a false medical diagnosis of this group of patients are identified as the misinterpretation of the deaf cultural specificity and the lack of understanding communication with them (Ubido, Huntington and Warburton, 2002). For later attitudes and communication with deaf people, the quality of prior contact with deaf individuals is important (De Laat et al., 2013). So, a positive experience and a positive attitude of students who are studying for healthcare professionals could contribute to a better understanding and improved communication with deaf patients in their future work. The purpose of the study was to collect data on the attitudes of students of medical schools towards their deaf and hard of hearing peers and their integration. Using the Inclusion of Deaf or Hard of Hearing Students Inventory (Hung 2005), which was translated and adapted to the Croatian language, we collected data on hearing students' perceived closeness to deaf and hard of hearing peers, the frequency of their prior voluntary contacts with deaf and hard of hearing persons, the perception of classroom atmosphere related to the integration of
\end{abstract}


the deaf into regular schools and does the school integrate deaf and hard of hearing students or not. The study included 328 high school students aged 15.5 to 16.5 years, among them were 270 girls and 58 boys from different medical programs. The findings showed that the perceived closeness with deaf and hard of hearing students is relatively high, meaning that attitudes towards them were positive. Girls have shown a higher perceived closeness compared to boys, but the difference, although statistically significant, was actually very small. No differences were noted depending on whether schools integrated deaf and hard of hearing students or not. The frequency of previous voluntary contacts with deaf and hard of hearing peers within the classroom is related to the perceived closeness with them. Students who have a more positive perception of the classroom atmosphere related to the effects of the integration of the deaf in personal and social life within the class and a more positive perception of the consequences of integration in class activities, showed a higher perceived closeness with deaf and hard of hearing peers, although the differences were very small.

Key words: medical school students, deaf and hard of hearing students, health care professionals 